\title{
Status of Readiness to Receive and Store Sister Rods from the R\&D Project
}

Fuel Cycle Research \& Development

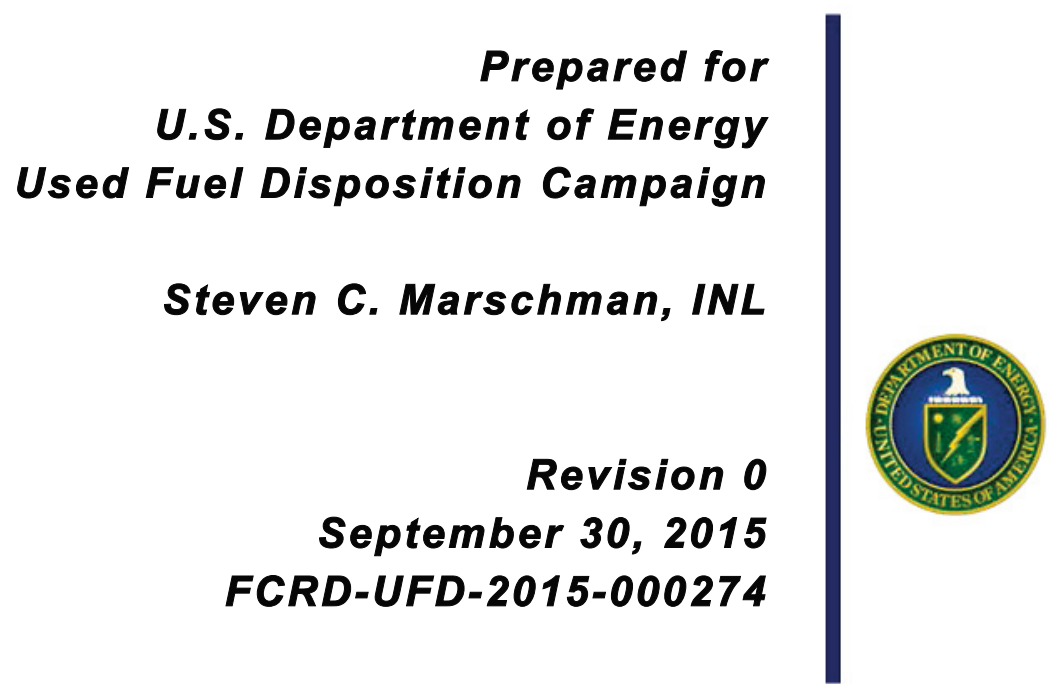




\section{DISCLAIMER}

This information was prepared as an account of work sponsored by an agency of the U.S. Government. Neither the U.S. Government nor any agency thereof, nor any of their employees, makes any warranty, expressed or implied, or assumes any legal liability or responsibility for the accuracy, completeness, or usefulness, of any information, apparatus, product, or process disclosed, or represents that its use would not infringe privately owned rights. References herein to any specific commercial product, process, or service by trade name, trade mark, manufacturer, or otherwise, does not necessarily constitute or imply its endorsement, recommendation, or favoring by the U.S. Government or any agency thereof. The views and opinions of authors expressed herein do not necessarily state or reflect those of the U.S. Government or any agency thereof. 
FCRD-UFD-2015-000274

\title{
Status of Readiness to Receive and Store Sister Rods from the R\&D Project
}

\author{
Steven C. Marschman
}

Revision 0

September 30, 2015

\author{
Idaho National Laboratory \\ Idaho Falls, Idaho 83415
}

http://www.inl.gov

Prepared for the

U.S. Department of Energy

Office of Used Nuclear Fuel Disposition Research and Development

Under DOE Idaho Operations Office Contract DE-AC07-05ID14517 
This page intentionally left blank. 


\section{SUMMARY}

This report fulfills the M3 milestone, M3FT-15IN0802014 Status of Readiness to Receive and Store Sister Rods from the R\&D Project, under Work Package Number FT-15IN080501.

The U.S. Department of Energy Office of Nuclear Energy (DOE-NE), Office of Fuel Cycle Technology, has established the Used Fuel Disposition Campaign (UFDC) to conduct the research and development activities related to storage, transportation, and disposal of used nuclear fuel and high-level radioactive waste. The mission of the UFDC is to identify alternatives and conduct scientific research and technology development to enable storage, transportation and disposal of used nuclear fuel (UNF) and wastes generated by existing and future nuclear fuel cycles. The UFDC Storage and Transportation staffs are responsible for addressing issues regarding the extended or long-term storage of UNF and its subsequent transportation. The near-term objectives of the Storage and Transportation task are to use a science-based approach to develop the technical bases to support the continued safe and secure storage of UNF for extended periods, subsequent retrieval, and transportation.

While low burn-up fuel [that characterized as having a burn-up of less than 45 gigawatt days per metric ton uranium (GWD/MTU)] has been stored for nearly three decades, the storage of high burn-up used fuels ${ }^{\mathrm{a}}$ is more recent. The DOE has funded a High Burn-Up (HBU) Confirmatory Data Project to confirm the behavior of used high burn-up fuel under prototypic conditions. The Electric Power Research Institute (EPRI) is leading a project team to develop and implement the Test Plan to collect this data from a UNF dry storage system containing high burn-up fuel. As part of that project, 25 "sister" fuel rods have been selected, removed from assemblies, and placed in a fuel container ready for shipment to a national laboratory. This report documents that status of readiness to receive the fuel if that fuel were to be sent to Idaho National Laboratory (INL).

INL is essentially ready to receive the fuel. However, permission from the State of Idaho to allow the fuel rods to be sent to INL has not been granted. Hopefully this will be resolved before DOE must make a decision to send the fuel elsewhere.

\footnotetext{
a "High burn-up" fuel has a burn-up level at or above approximately 45 gigawatt-days per metric ton of uranium (GWD/MTU).

${ }^{\mathrm{b}} \mathrm{A}$ 'sister rod' is a rod from a different assembly than the one that will be placed into the HBU Confirmatory Data Project storage cask, but with properties similar to that of the assembly to be emplaced in the cask.
} 


\section{CONTENTS}

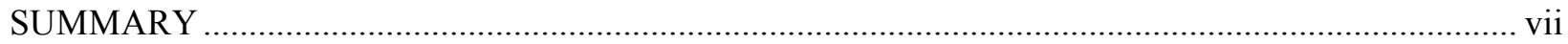

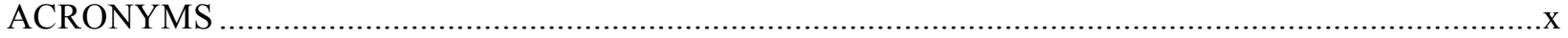

REGISTRATIONS AND TRADEMARKS …............................................Error! Bookmark not defined.

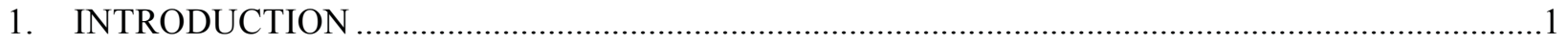

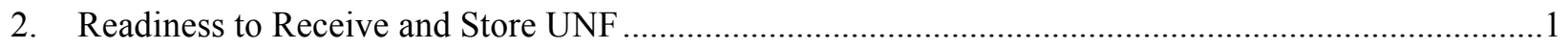

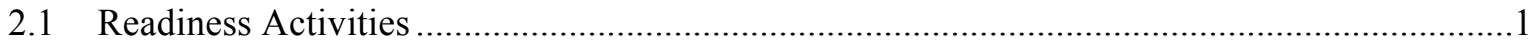

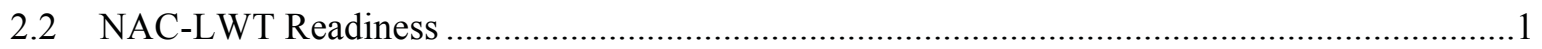

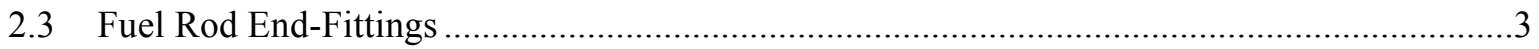

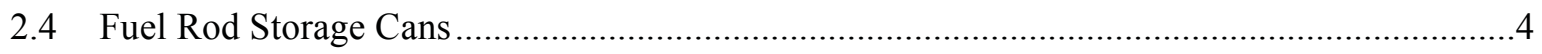

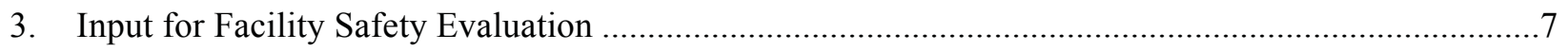

4. VERIFICATION OF TOOLS NEEDED FOR RECEIPT …............................................................

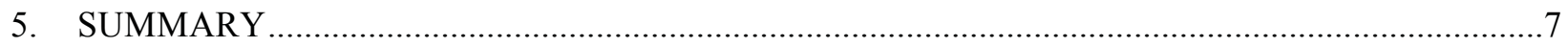

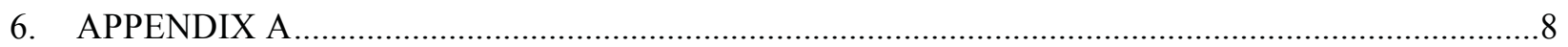

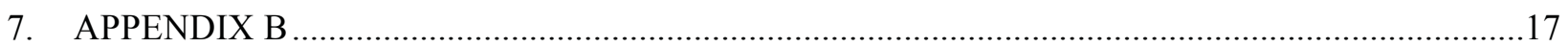




\section{FIGURES}

Figure 2.1. Unloading the NAC-LWT from its ISO transport container in the HFEF truck lock................ 2

Figure 2.2. Removing the bolts from the lid of the NAC-LWT cask.................................................. 3

Figure 2.3. Type D end fittings that would be attached to each of the 25 sister rods. .............................. 4

Figure 2.4. Fit-up of the 14-rod storage can components.................................................................... 5

Figure 2.5. Both 14-rod storage cans during fit-up and welding ........................................................ 5

Figure 2.6. Fully assembled 14-rod storage ready for shipment to INL. ............................................... 6 


\section{ACRONYMS}

EPRI Electric Power Research Institute

GWD gigawatt-day

HBU High Burn-Up

HFEF Hot Fuels Examination Facility

INL Idaho National Laboratory

MTU metric ton uranium (or heavy metal)

ORNL Oak Ridge National Laboratory

UFDC used fuel disposition campaign

UNF used nuclear fuel 
This page intentionally left blank. 


\section{STATUS OF READINESS TO RECEIVE AND STORE SISTER RODS FROM THE R\&D PROJECT}

\section{INTRODUCTION}

Low burn-up fuel [that characterized as having a burn-up of less than 45 gigawatt days per metric ton uranium (GWD/MTU)] has been stored in dry storage systems for nearly three decades. High burn-up used fuels ${ }^{\mathrm{c}}$ have only begun to be placed in dry storage in the past decade or so. As of December 2012, approximately 200 dry storage casks have been loaded with at least some high burn-up used nuclear fuel (UNF). Furthermore, almost all UNF being discharged from reactors in the U.S. is now high burn-up. Since high burn-up UNF has different mechanical properties than lower burn-up UNF, additional data on high burn-up UNF under typical conditions are needed to better understand those differences. The DOE has funded a HBU Confirmatory Data Project to confirm the behavior of high burn-up used fuel under prototypic conditions. [1] The Electric Power Research Institute (EPRI) is leading a project team to develop and implement the Test Plan to collect this data from a UNF dry storage system containing high burn-up fuel. The Test Plan for this dry storage project outlines the data to be collected; the high burn-up fuel to be included, and the storage system design, procedures, and licensing necessary to implement the Test Plan. As part of that project, 25 "sister" fuel rods have been selected, removed from assemblies, and placed in a fuel container ready for shipment to a national laboratory. This report documents that status of readiness to receive the fuel if that fuel were to be sent to Idaho National Laboratory (INL).

\section{Readiness to Receive and Store UNF}

\subsection{Readiness Activities}

There are many activities that must be accomplished to establish readiness to receive and store the sister rods. These include:

- Readiness to receive and handle the transportation cask

- Ensure the receiving facility safety basis can accept the hazards associated with the material.

- Verify tools and materials for the fuel receipt, handling, and storage are ready.

\subsection{NAC-LWT Readiness}

The NAC-LWT transport cask was selected for shipping the fuel from the North Anna Power Station to Idaho National Laboratory (INL). A 25 fuel rod canister was supplied to North Anna and placed in the spent fuel pool. The selected fuel rods were extracted from the fuel assemblies and placed in the container by Westinghouse and AREVA fuel handlers working the Dominion fuel handlers at North Anna.

Two programs at INL have a need to transport UNF to the lab, UFDC and the Joint Fuel Cycle Studies (JFCS) program. JFCS needs fuel to support an electrochemical fuel recycling study with the Republic of Korea. That shipment was scheduled to come to INL in the summer of 2015, several months in advance of the UFDC sister rods. JFCS paid for the Readiness Assessment that demonstrated INL readiness to receive, handle, unload, decontaminate, and return the cask to the vendor (NAC International Inc.). The Readiness Assessment was conducted in March, 2015, and was successfully completed. INL is now

\footnotetext{
c "High burn-up" fuel has a burn-up level at or above approximately 45 gigawatt-days per metric ton of uranium (GWD/MTU).

${ }^{\mathrm{d}}$ A 'sister rod' is a rod from a different assembly than the one that will be placed into the HBU Confirmatory Data Project storage cask, but with properties similar to that of the assembly to be emplaced in the cask.
} 
qualified (in accordance with DOE Conduct of Operations) to handle the NAC-LWT for a period of two years from April 1, 2015. There qualification will expire April 1, 2017 unless INL receives and handles the cask before that date. If the cask is received and handled before April 1,2017, the qualification period extends two years from that new receipt date.

JFCS invested about $\$ 650 \mathrm{~K}$ to complete the Readiness Assessment. This included all the procedure updates, training, operations at the Hot Fuel Examination Facility (HFEF), cask rental for two weeks, and the cost for NAC International Inc. staffs to travel to INL and assist in the training efforts. The cask was brought into the facility and handled exactly as it would be if it were filled with UNF. The cask was brought into the HFEF truck lock in its ISO container, unloaded, lowered into the cask tunnel, mated to the hotcell, opened, stainless steel simulated fuel rods loaded out of the cask into the hotcell, and then the cask was removed, surveyed, and returned to its ISO container. Figure 2.1 shows the NAC-LWT cask being removed from its ISO container to be placed in the HFEF cask cart. Figure 2.2 shows workers removing the bolts to the lid of the cask in preparation for moving under the hotcell and mating the cask to the hotcell. Appendix A contains a report that documents the outcome of the Readiness Assessment. Appendix B contains illustrations that show the sequence of events used for handling the NAC-LWT cask in HFEF.

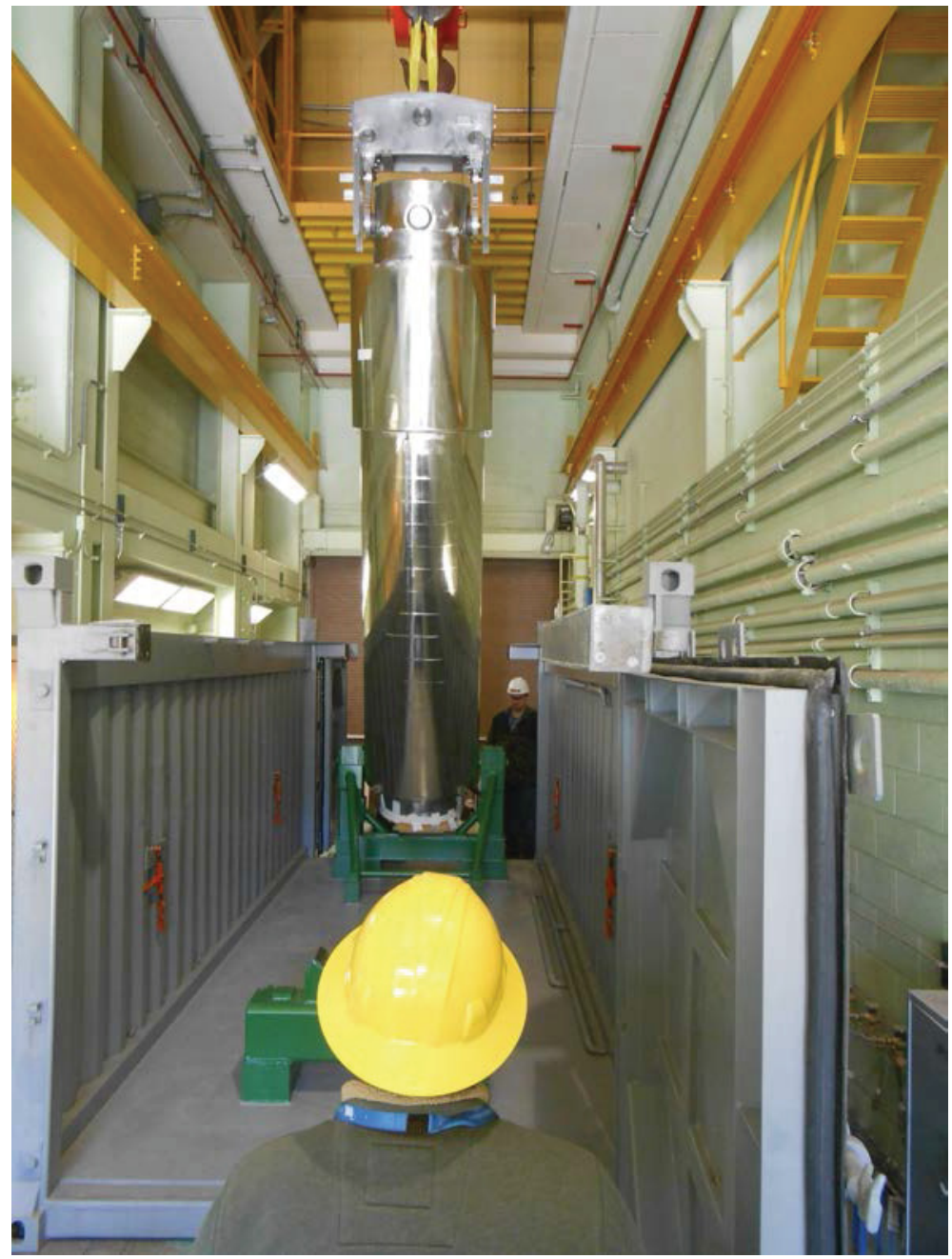

Figure 2.1. Unloading the NAC-LWT from its ISO transport container in the HFEF truck lock. 


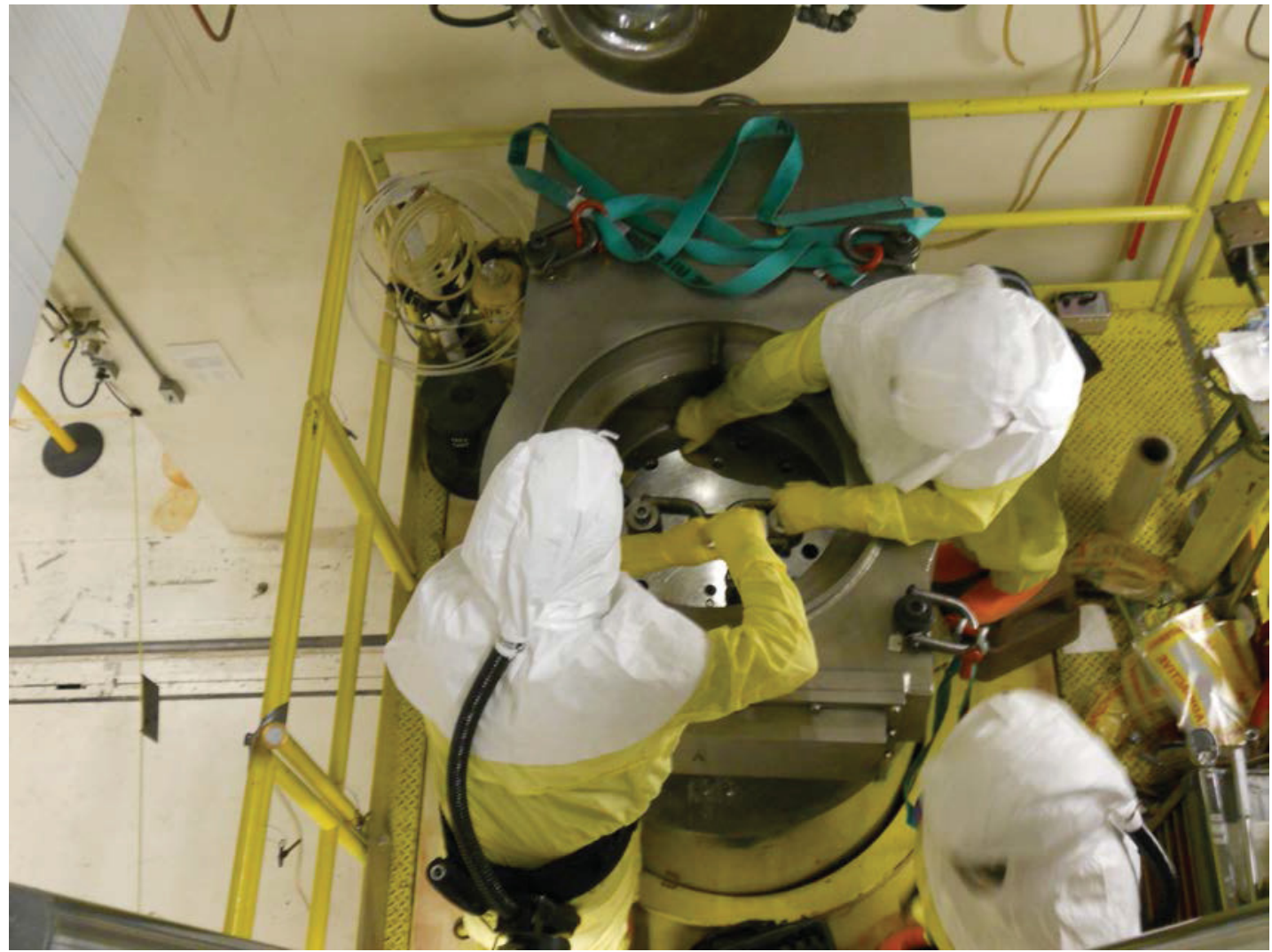

Figure 2.2. Removing the bolts from the lid of the NAC-LWT cask.

\subsection{Fuel Rod End-Fittings}

All Post-Irradiation Examination (PIE) stations, cranes, and the large electo-mechanical manipulator inside the HFEF main hotcell utilize a standardized fitting that allows the fuel rods to be moved, handled, and mounted to the PIE stations. A "Type D end fitting" has an adjustable collet, allowing them to be used on fuel rods up to $0.375 \mathrm{in.}(9.525 \mathrm{~mm}$ ) in diameter (Westinghouse $17 \times 17$ fuel rods are 0.374 in [9.5 $\mathrm{mm}$ ] in diameter). Twenty-five of these fittings were fabricated in preparation of fuel receipt. These fittings would be fitted to 23 of the fuel rods immediately upon removal from the fuel container. Two of the Westinghouse Zircaloy-4 clad fuel rods were pulled from the bottom of fuel assemblies and were inserted into the fuel container "upside down," as they have been since they removed from their assemblies. These rods will be turned end-for-end, then the end fittings will be attached. It is desired to have all fuel rods in the "up" orientation for consistency. 


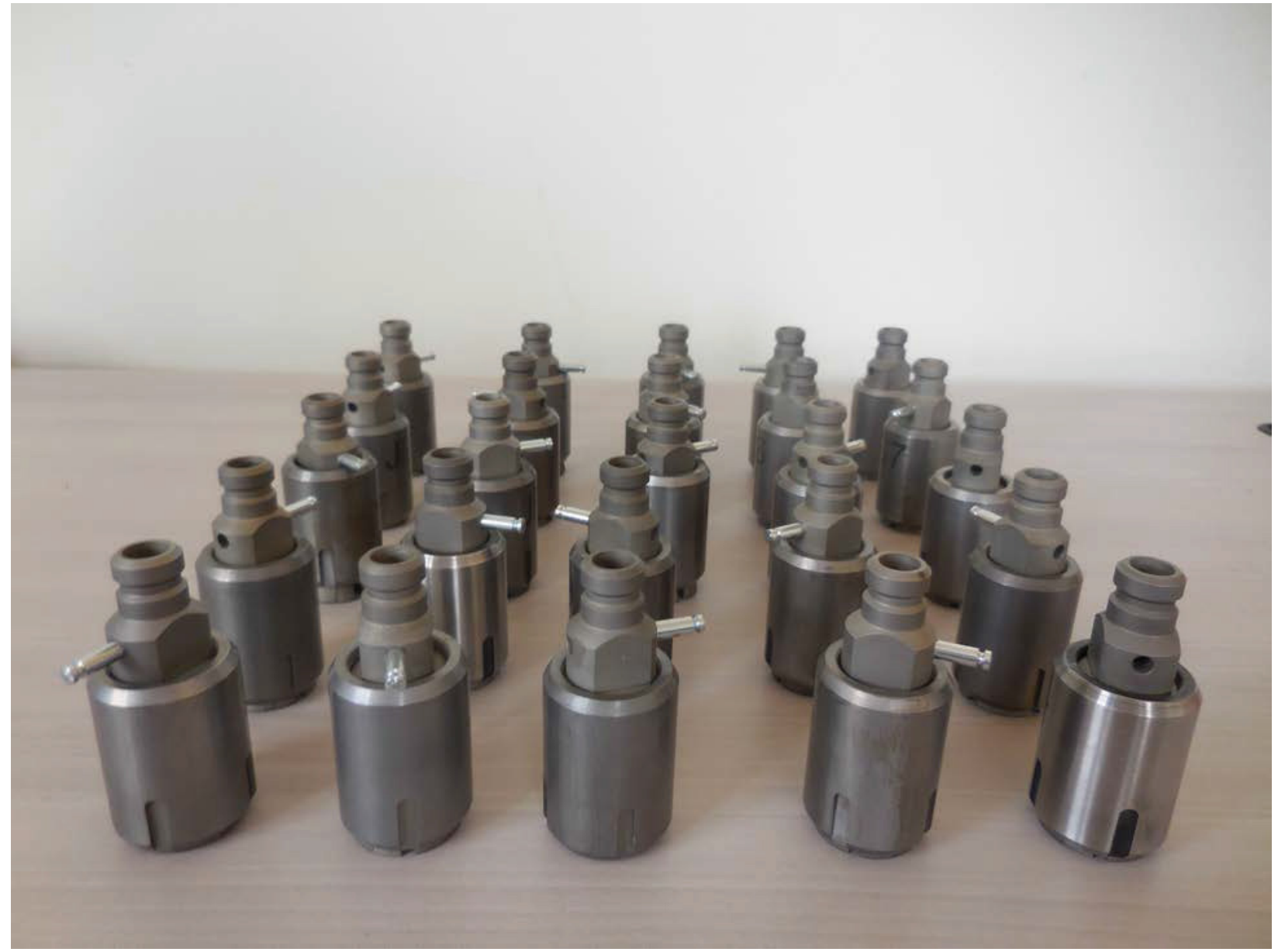

Figure 2.3. Type D end fittings that would be attached to each of the 25 sister rods.

\subsection{Fuel Rod Storage Cans}

Storage cans are needed to protect and hold the sister rods once they are removed from the NAC-LWT fuel container. The rods will be pulled from the container, end fittings attached, visually inspected, then placed in a known (and recorded) location in the storage cans. The original HFEF designs for these cans accommodated either 8 or 14 fuel rods. To house 25 rods, three cans would be needed and those cans would take up valuable real estate within the Material Balance Area storage wells in the middle of the HFEF main hotcell. Since new cans had to be fabricated, the decision was made to change the can design to hold 14 rods each. The redesign and subsequent criticality and nuclear safety analyses were completed. The new storage cans were fabricated and delivered to INL in August 2015. They have been inspected and are ready for use. These cans also serve as "sealed" containers, which; when the fuel is inside and the can's lids securely attached, allow the contents to be exempted from the facility "material-at-risk" inventory. This is important for nuclear safety because there is a limit on how much fissile material and other radionuclides can (or should) be vulnerable during an accident (should one ever occur). Sealed containers reduce the risk of material becoming involved in several of the accident scenarios documented in the HFEF Design Safety Basis document. The new cans are shown in Figures 2.4 to 2.6. Two cans were made. 


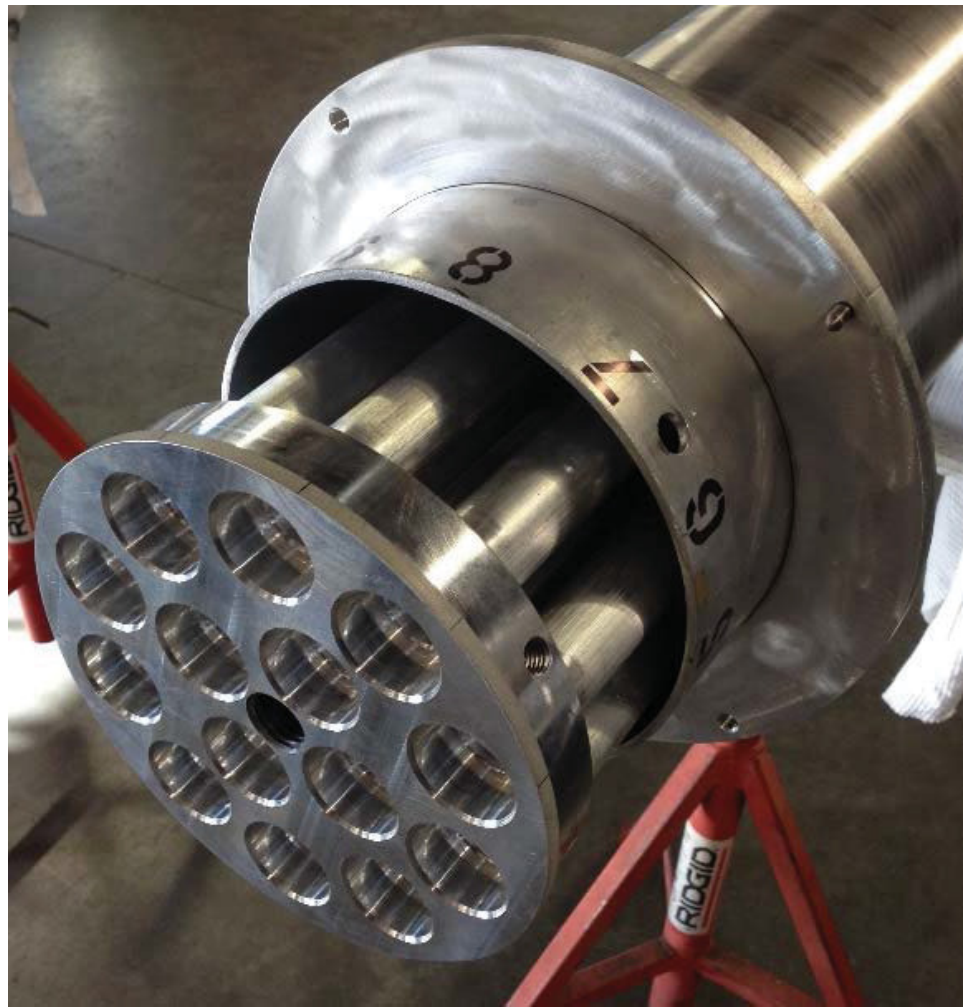

Figure 2.4. Fit-up of the 14-rod storage can components.

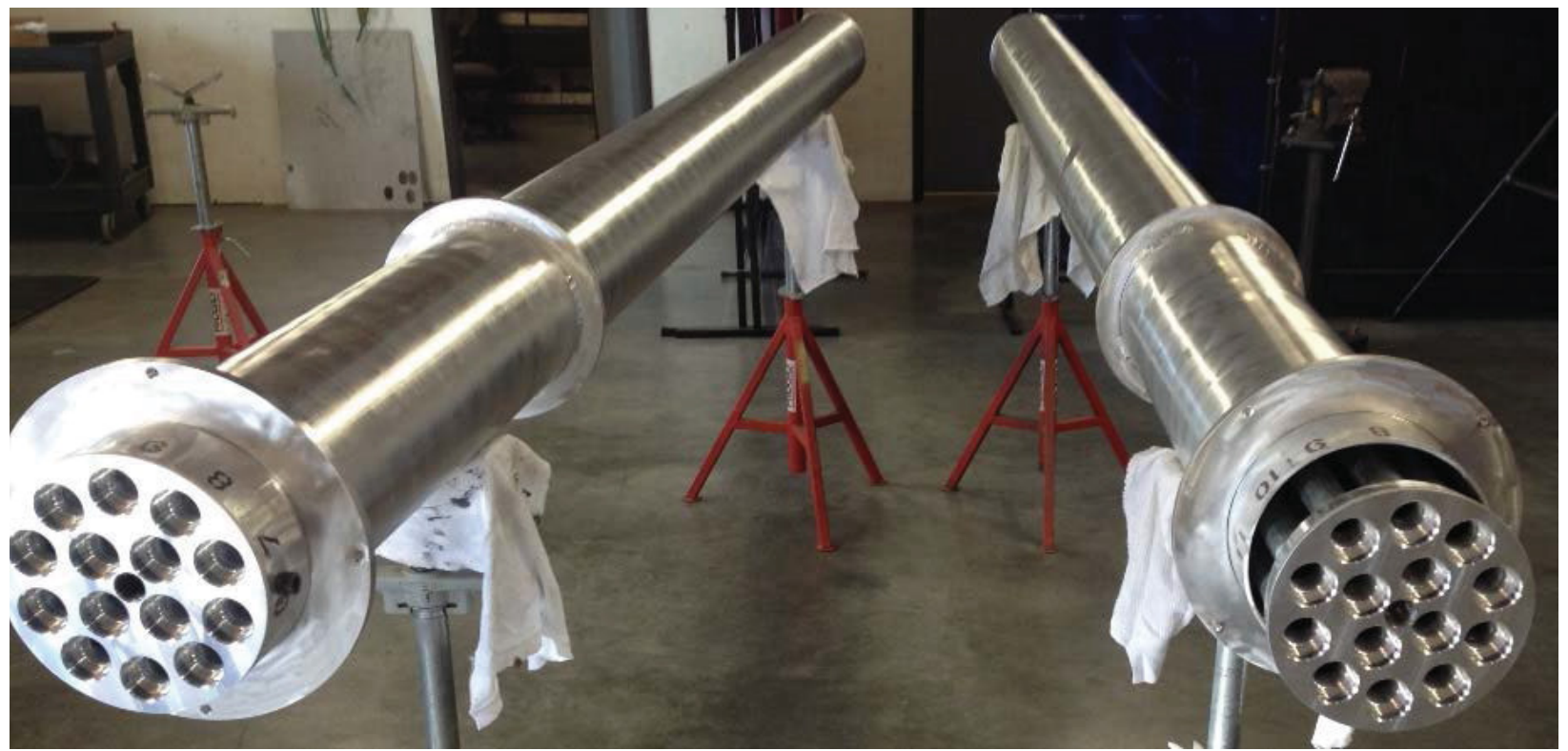

Figure 2.5. Both 14-rod storage cans during fit-up and welding. 


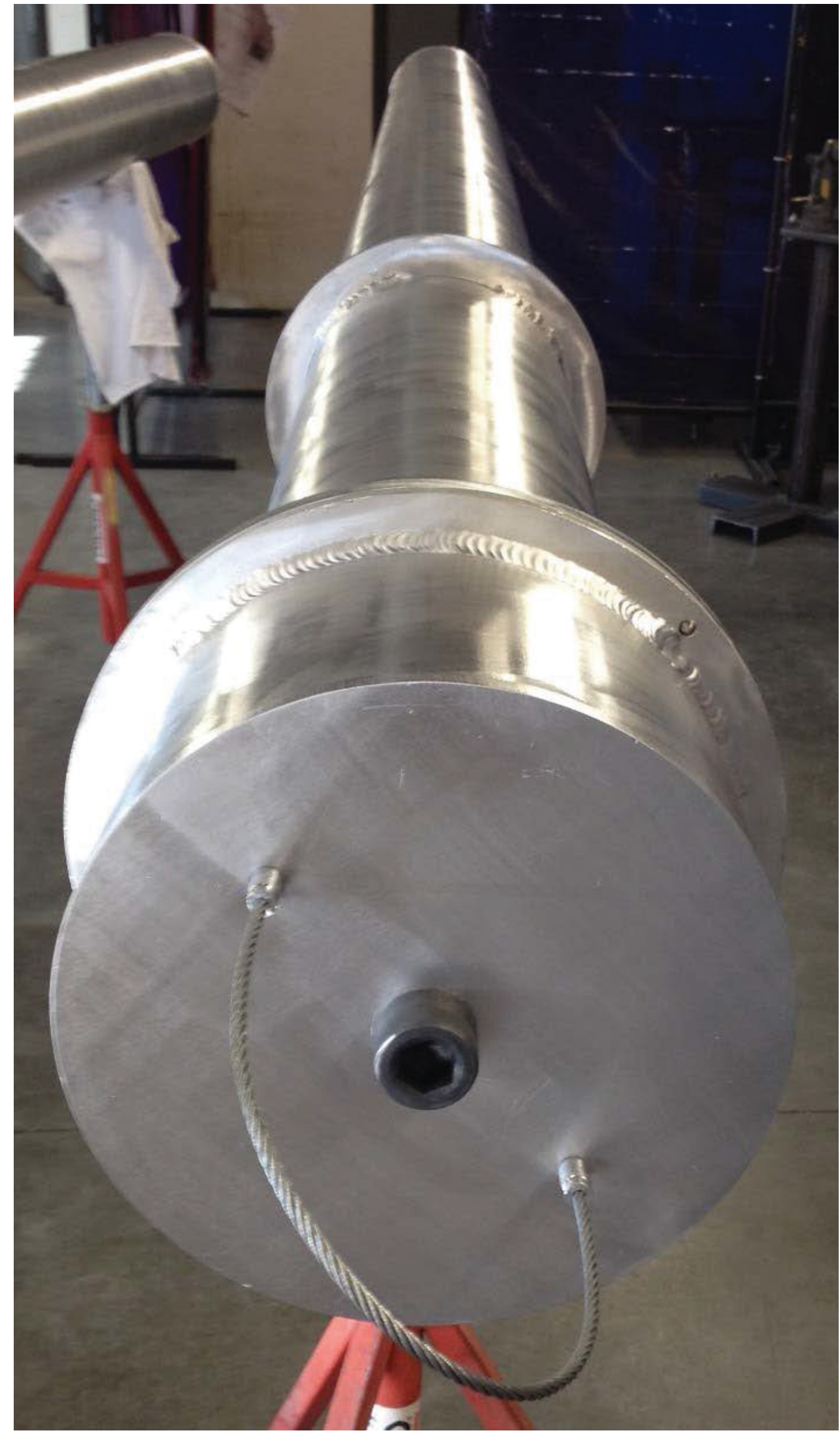

Figure 2.6. Fully assembled 14-rod storage ready for shipment to INL. 


\section{Input for Facility Safety Evaluation}

A Technical Evaluation Study (TEV) was completed to provide background information on the sister rods that have been selected for shipment to INL. This information was used for analyses to ensure compliance with facility safety basis requirements (e.g. evaluation for compliance with facility Technical Safety Requirements, Material Balance Areas, National Emission Standards for Hazardous Air Pollutants, and Safeguards. This TEV contains information proprietary to Dominion, Westinghouse, and AREVA and cannot be reproduced as part of this report. Oak Ridge National Laboratory contributed to the TEV by providing ORIGEN calculations for the 25 sister fuel rods. The TEV contains those calculations, an estimate of $\mathrm{Pu}-239$ equivalent curies in each rod (useful for waste evaluation and for respirable hazard predictions in accident analyses), an evaluation of potential surface crud on the fuel, source and background data on the fuel, and total fission gas content of each rod.

No Unresolved Safety Questions were found, which is an indication of no significant risk to the facility or workers related to receiving and storing the sister rods.

\section{VERIFICATION OF TOOLS NEEDED FOR RECEIPT}

All tools needed for receiving and storing the sister rods are present and ready for use. Some of the tools needed for cask handling are supplied by NAC International Inc. and come along with the cask during transport. The survey of tools was conducted during the JFCS dry run of the NAC-LWT cask.

\section{SUMMARY}

INL is ready to receive the NAC-LWT cask with the 25 sister fuel rods, handle the cask, unload the cask, move the sister fuel rods into safe storage, and return the cask to the owner at the completion of those activities. 


\section{APPENDIX A}

This appendix is a copy of a report, IRT Readiness to Receive Used Fuel at HFEF. Though written for the JFCS, the work applies directly to the UFDC receipt of sister rods at INL for UFDC. 


\section{IRT Readiness to Receive Used Fuel at HFEF \\ Fuel Cycle Research \& Development}

Prepared for

U.S. Department of Energy Joint Fuel Cycle Studies

Steve Warmann

Idaho National Laboratory

June 2, 2015 NE FCRD-JFCS-2015-00053

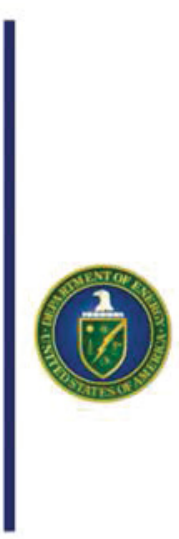




\section{DISCLAIMER}

This information was prepared as an account of work sponsored by an agency of the U.S. Government. Neither the U.S. Government nor any agency thereof, nor any of their employees, makes any warranty,

expressed or implied, or assumes any legal liability or responsibility for the accuracy, completeness, or usefulness, of any information, apparatus, product, or process disclosed, or represents that its use would not infringe privately owned rights. References herein to any specific commercial product, process, or service by trade name, trade mark, manufacturer, or otherwise, does not necessarily constitute or imply its endorsement, recommendation, or favoring by the U.S. Government or any agency thereof. The views and opinions of authors expressed herein do not necessarily state or reflect those of the U.S. Government or any agency thereof 
IRT Readiness to Receive Used Fuel at HFEF

06/02/2015

\section{SUMMARY}

The purpose of this report is to summarize the readiness activities which have been completed at the Hot Fuel Examination Facility (HFEF) to demonstrate readiness to receive pressurized water reactor (PWR) fuel in support of the Joint Fuel Cycle Studies (JFCS) project. All equipment, procedures, operator training, and contractual documents are in place for receiving the fuel. 
iv

IRT Readiness to Receive Used Fuel at HFEF $06 / 02 / 2015$

\section{CONTENTS}

iii

1. INTRODUCTION

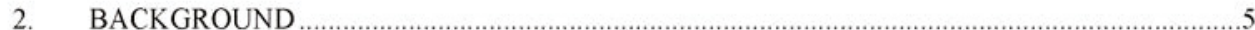

3. CASK RECEIPT DRY RUN AT HFEF ……

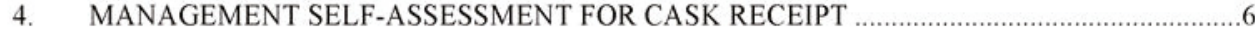

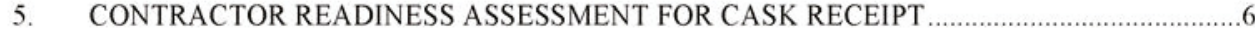

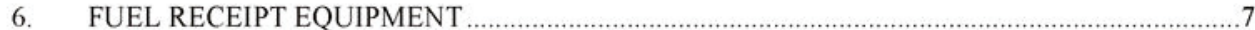

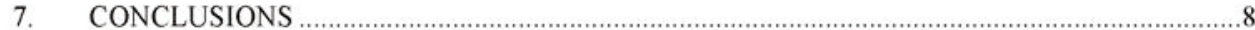


IRT Readiness to Receive Used Fuel at HFEF

06/02/2015

\section{IRT READINESS TO RECEIVE USED FUEL AT HFEF}

\section{INTRODUCTION}

Spent commercial PWR nuclear fuel is required to perform the Integrated Recycling Test at HFEF as part of the JFCS program. For this test, a cask shipment of PWR fuel rods must be received at HFEF. The fuel rods will be removed from the cask and transferred to a storage location within the HFEF main hot cell, where they will await mechanical processing activities in preparation for electrochemical recycling tests.

The purpose of this report is to summarize the readiness activities which have been completed at HFEF to demonstrate readiness to receive PWR fuel in support of the JFCS project. All equipment, procedures, operator training, and contractual documents are in place for receiving the fuel.

\section{BACKGROUND}

The U.S. DOE; the Republic of Korea Ministry of Education, Science and Technology; and the Ministry of Knowledge Economy have begun a cooperative research effort to examine a range of civilian nuclear fuel cycle options relevant to the Republic of Korea. This broad collaboration will last 10 years and is known as the JFCS program. A key component of the collaboration is an evaluation of the recycling of used light-water reactor (LWR) oxide fuels via electrochemical technologies and a fast reactor. This evaluation of electrochemical recycling will focus on the improvement of process knowledge such that the technology's benefits to an overall fuel cycle can be better quantified and to evaluate associated safeguards and security methods and technologies.

In order to obtain real process knowledge by which to evaluate the electrochemical recycling of LWR fuel, an integrated testing activity at approximately kilogram-scale in HFEF is planned. This activity will provide material balance data, evaluate process flowsheet options, and serve as a test bed for demonstration of safeguards and security technologies. It also will include the fabrication of several metal fuel rodlets, their irradiation in the Advanced Test Reactor (ATR) at the Idaho National Laboratory (INL), and post-irradiation examination in HFEF.

\section{CASK RECEIPT DRY RUN AT HFEF}

On 27 February 2015, the NAC-LWT arrived at HFEF for purposes of practicing fuel receipt operations in advance of readiness activities. The two primary procedures, HFEF-OI-6205 "NAC-LWT Cask" and HFEF-LI-0077 "Unloading the NAC-LWT Cask into the HFEF Main Cell," were validated during this dry run. A dummy payload was inserted into the cask once opened such that full operations from receipt of the cask to unloading a payload into storage within the hot cell could be worked to ensure everything was in order for arrival of the actual payload at a later date. The dummy rod was successfully unloaded from the cask and placed into storage within the hot cell illustrating that cask operations and hot cell operations were fully prepared. 


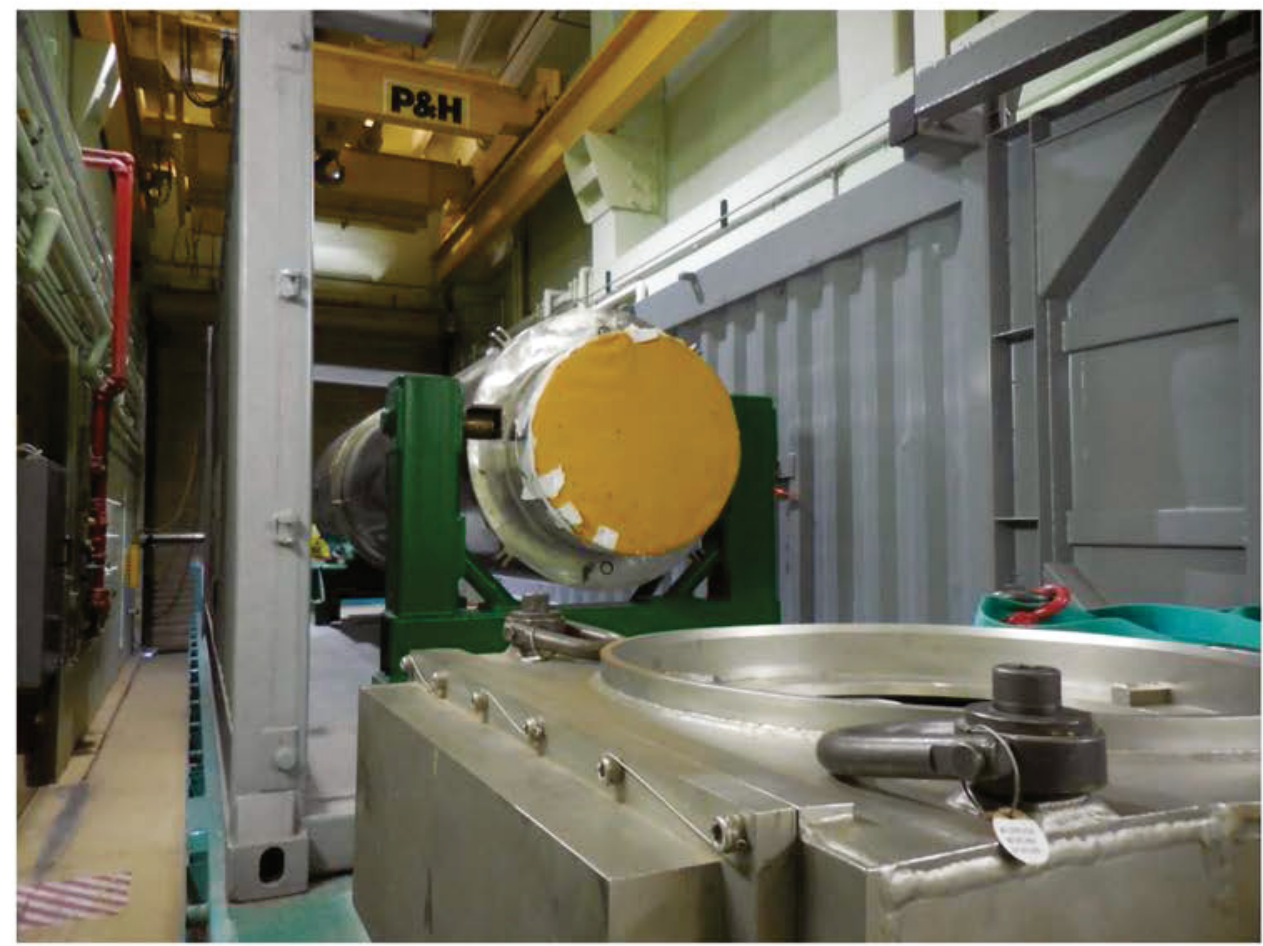

Figure 1. NAC-LWT cask in background with NAC-provided shutter shield in foreground during dry run operations at HFEF.

\section{MANAGEMENT SELF-ASSESSMENT FOR CASK RECEIPT}

Following the cask dry run, a management self-assessment (MSA) was performed to demonstrate that all paperwork was in order for an upcoming readiness assessment. The MSA was completed in early March 2015. The MSA was performed with the same evaluation criteria to be investigated during the contractor readiness assessment (CRA). Facility procedures and training were the primary focus of the MSA. The MSA was completed successfully leading to initiation of the CRA.

\section{CONTRACTOR READINESS ASSESSMENT FOR CASK RECEIPT}

The CRA was completed successfully in March of 2015. The CRA included a live demonstration of the cask handling operations. The cask handling procedure, HFEF-OI-6205, was performed while a CRA team observed the evolution. Over the span of several weeks, the cask operations were performed twice, once for the dry run and once for the CRA observed evolution. A NAC technical representative participated in the activities to provide the operators with mentoring on cask handling. 
IRT Readiness to Receive Used Fuel at HFEF $06 / 02 / 2015$

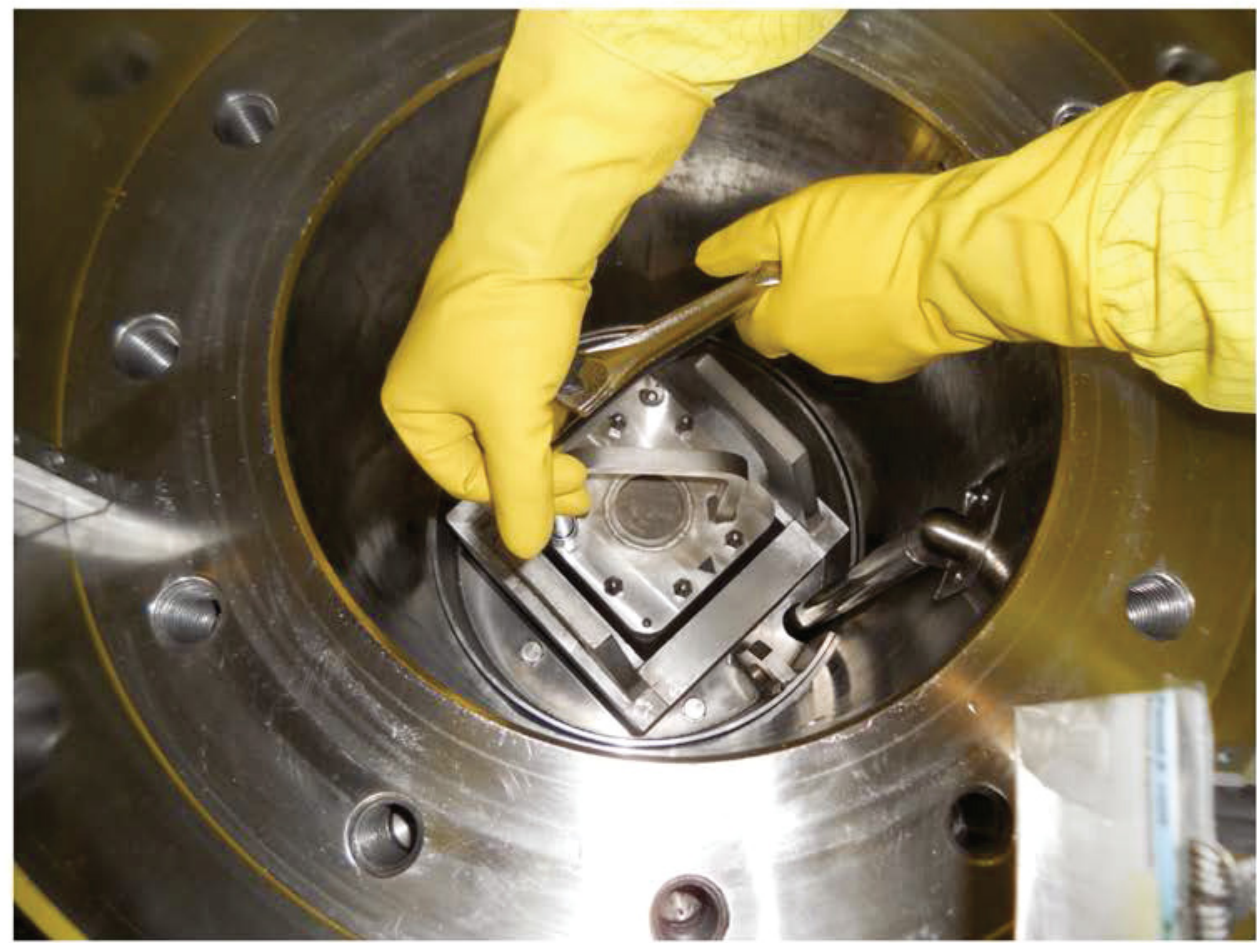

Figure 2. Internal PWR canister being opened while the cask was on the cask cart at HFEF.

\section{FUEL RECEIPT EQUIPMENT}

In order to perform the readiness activities and in preparation for later receipt of the actual used fuel payload, a large amount of equipment required fabrication. The following equipment has been fabricated and is ready to be used for the fuel receipt:

- Aluminum Half Covers - Used to prevent inadvertent release of materials into the cask while mated to the hot cell.

- 12-Element Storage Containers - Used to store the fuel in the pits within the HFEF Main Cell.

- Negator Spring Hook - Used to rig fuel element handling equipment to the hot cell crane.

- Gripper - Used to interface between the Negator Spring Hook and the End Fitting attached to the fuel elements.

- End Fittings - Used to securely grip fuel elements within the hot cell for subsequent handling.

- Cask Spacer - Used within the NAC-LWT cask to support the PWR basket at a height within the hot cell such that manipulators can be used to attach end fittings.

- Grapples - Used to grapple the Cask Spacer and PWR basket for handling within the hot cell. 
IRT Readiness to Receive Used Fuel at HFEF $06 / 02 / 2015$

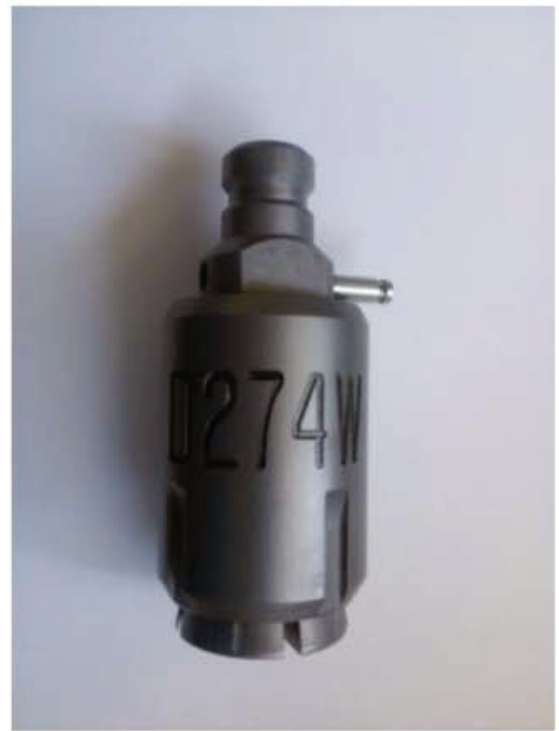

Figure 3. Type D end fitting used to securely grip the fuel rods.

\section{CONCLUSIONS}

A cask dry run, MSA, CRA, and CRA observed evolution were completed in March 2015 to demonstrate readiness to receive the used fuel feedstock at HFEF for the JFCS program. All equipment, procedures, and training were validated and demonstrate final readiness for the actual shipment of fuel from the commercial reactor site. 


\section{APPENDIX B}

The following illustrations show the sequence of events for unloading and loading the NAC International Inc. NAC-LWT transport cask at HFEF. 


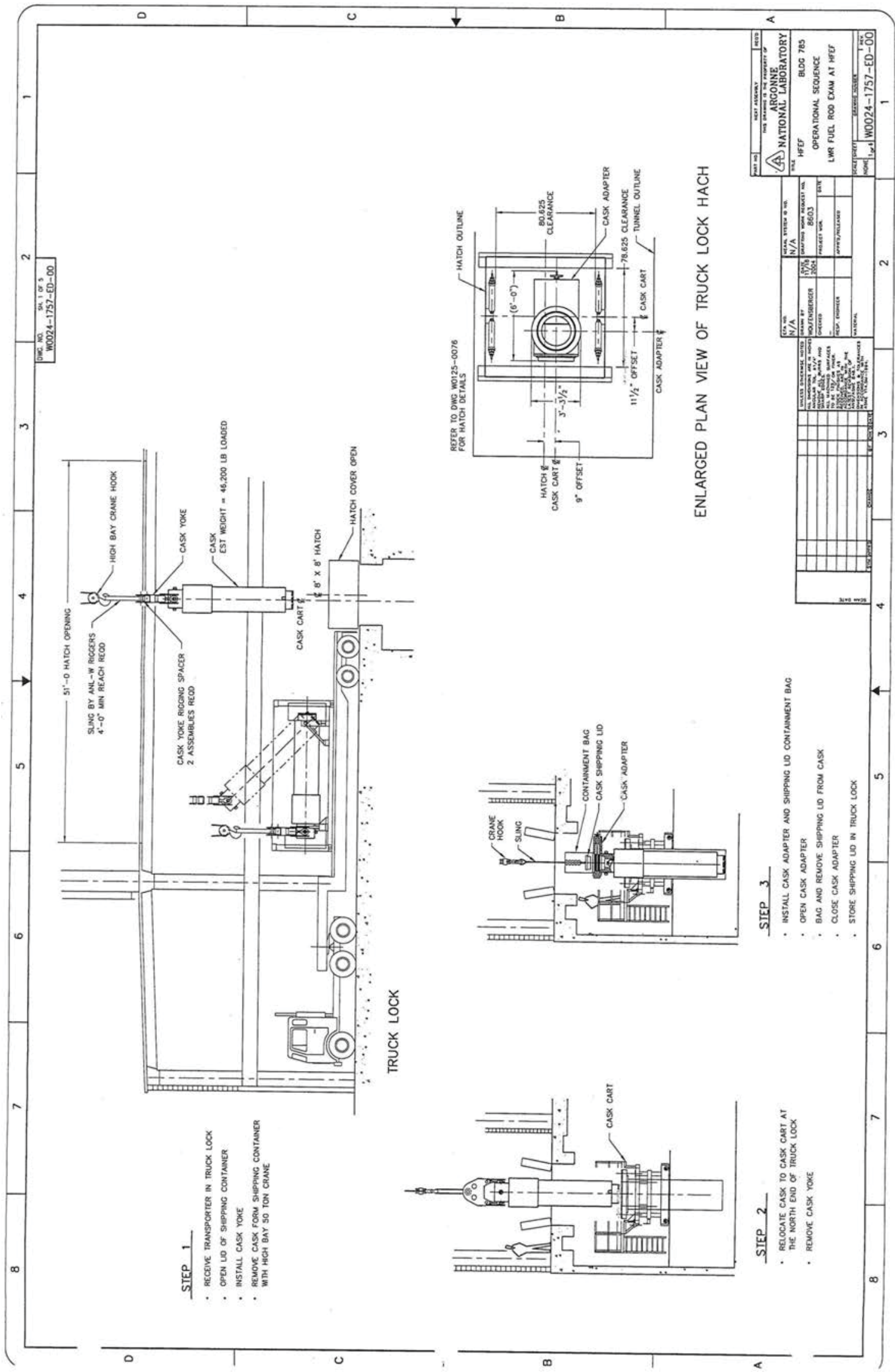




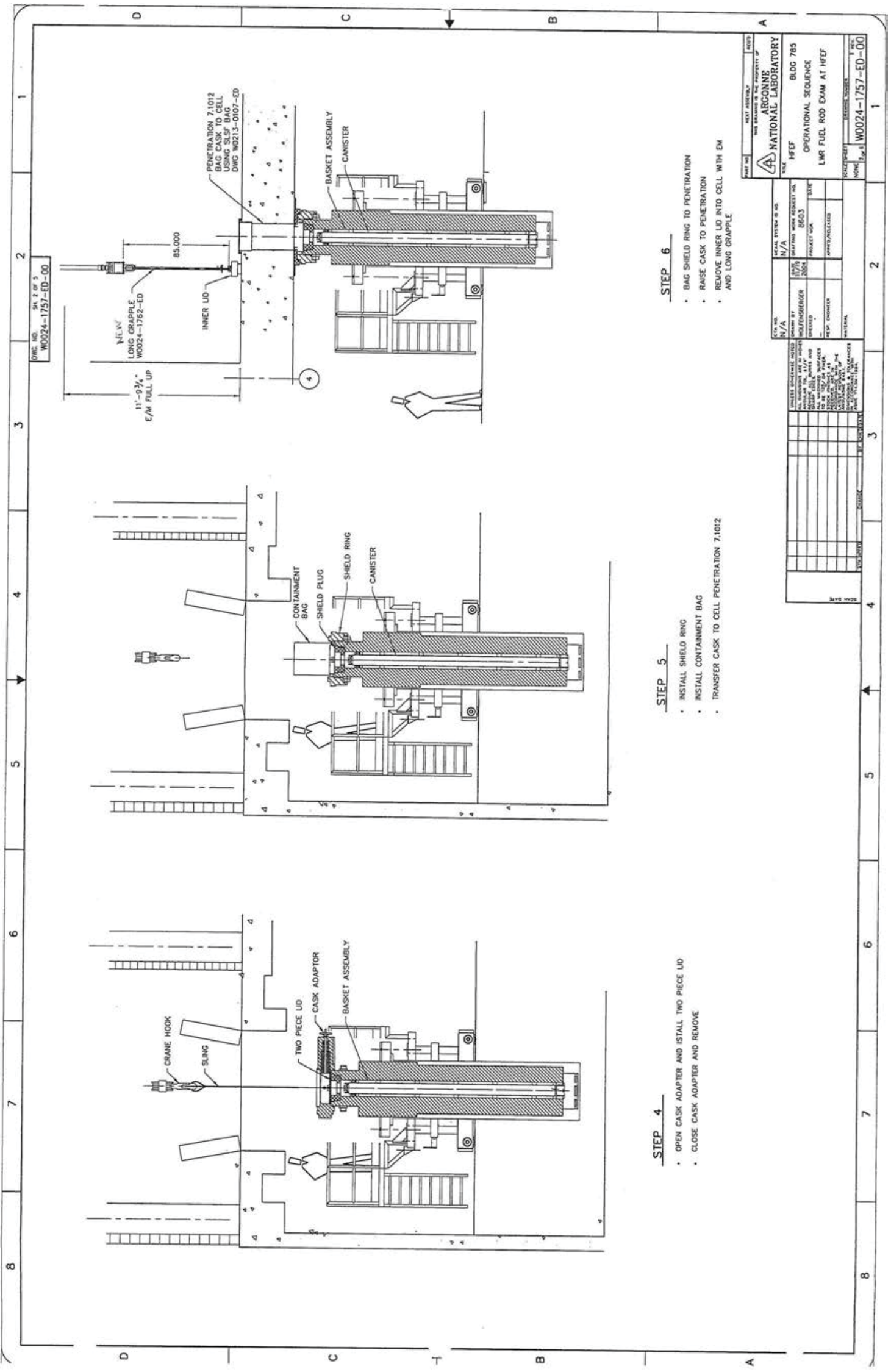




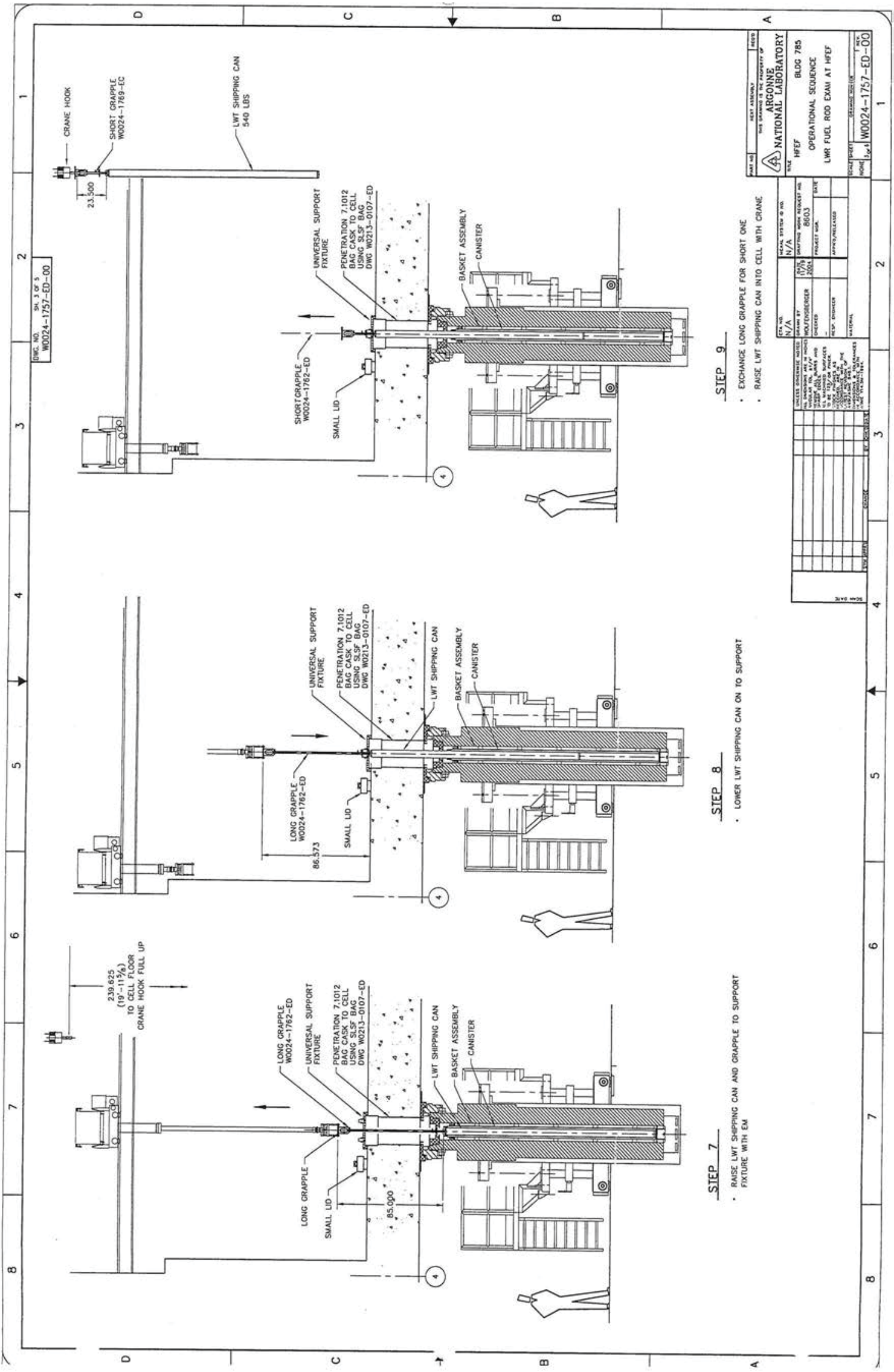




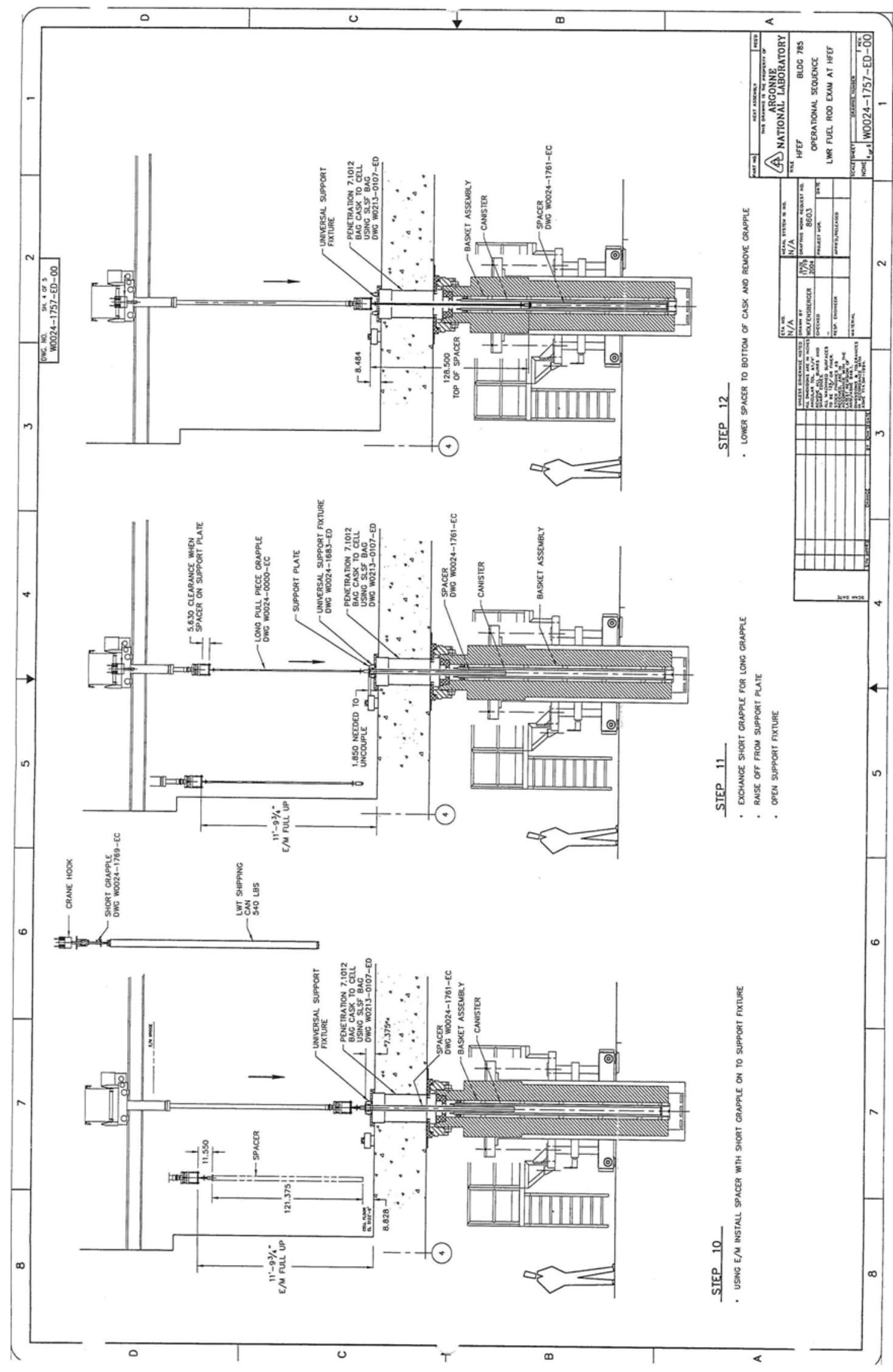




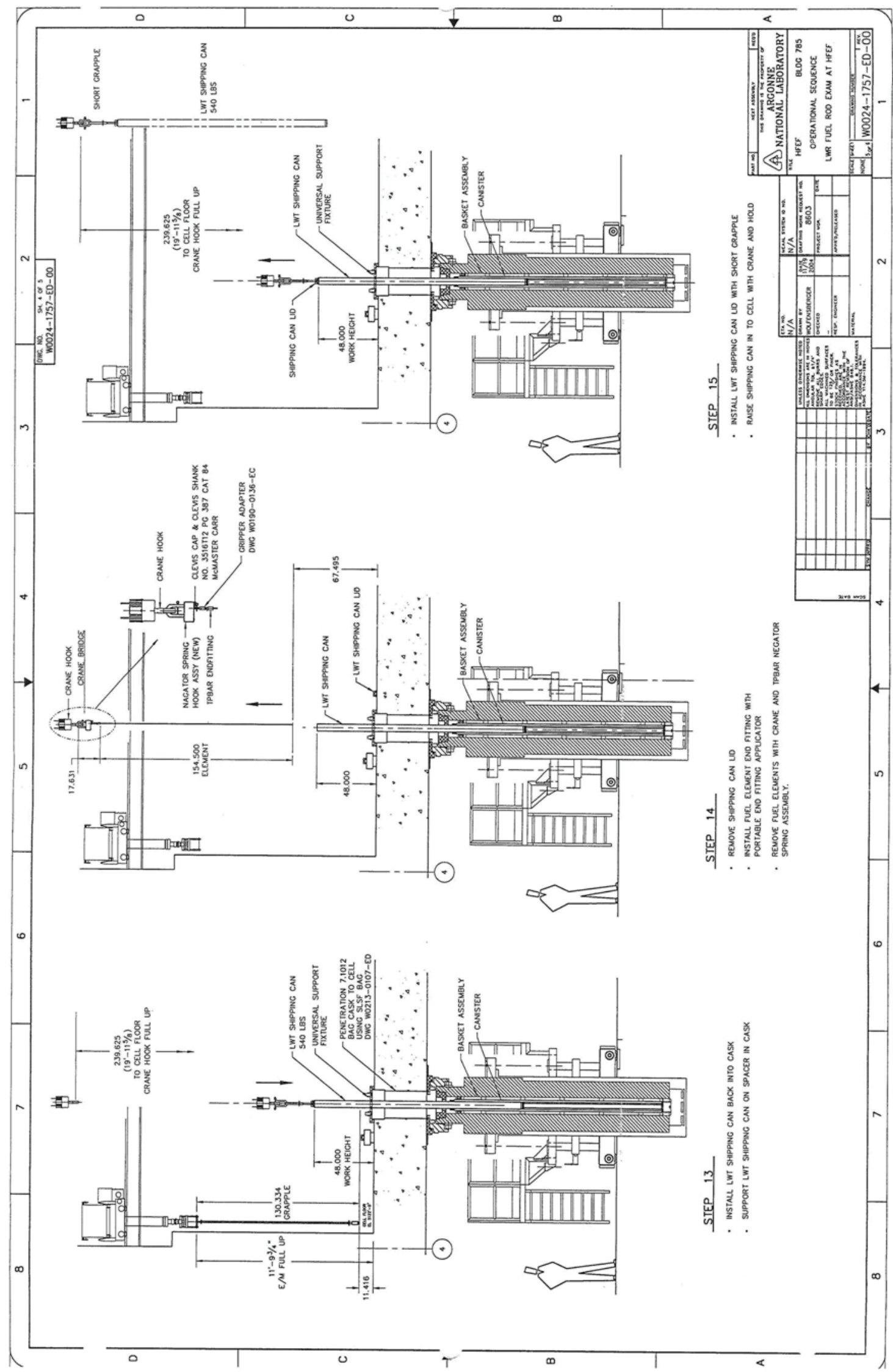




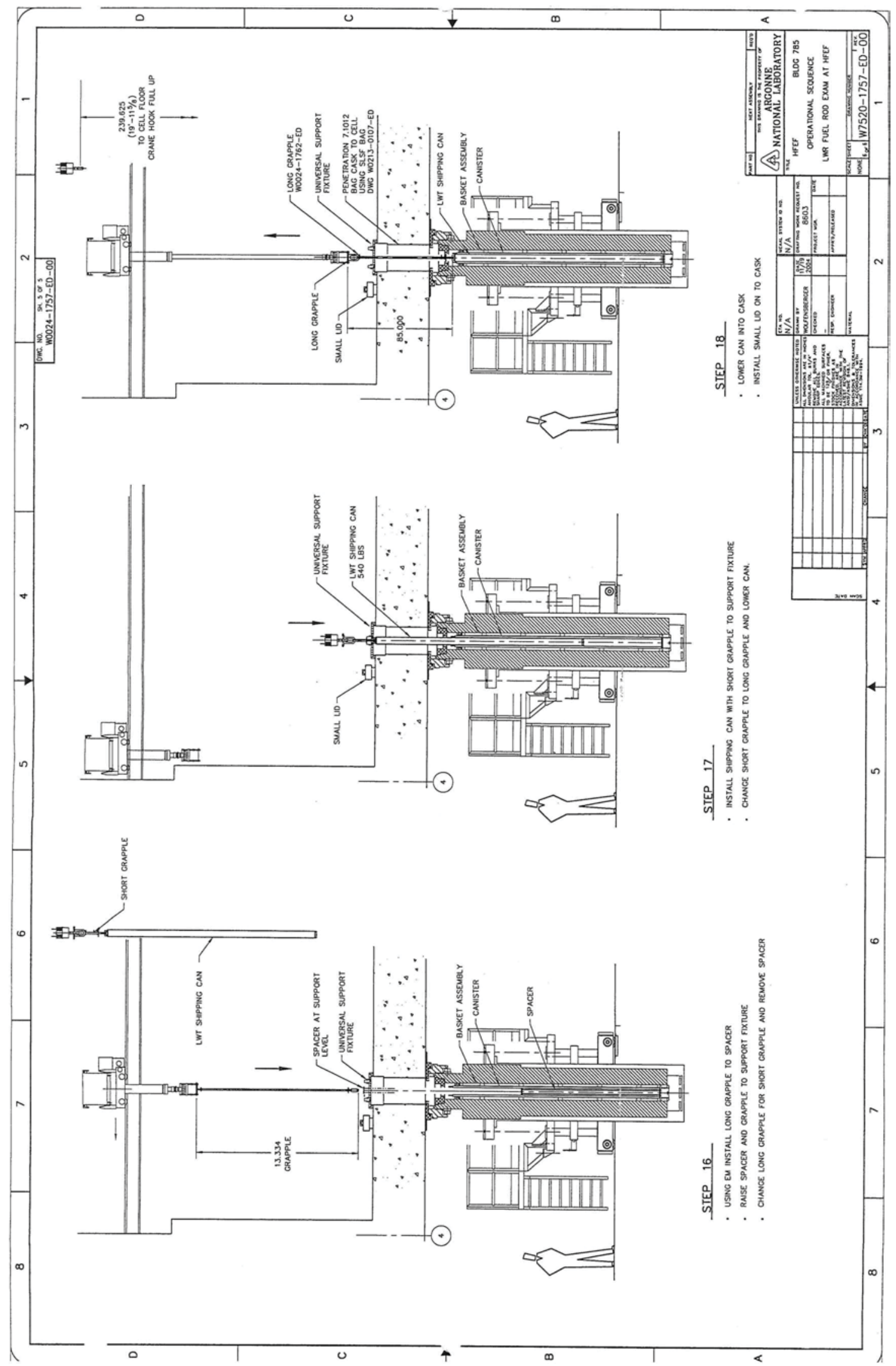


